\title{
Reflection of Christian ideological orientation through liturgical symbolism in P. Tchaikovsky's opera music
}

\author{
Kateryna Nemchenko* \\ Larisa Loboda* \\ Anatoliy Nosulya"* \\ Olena Kuchma"to \\ *Corresponding author, Odessa Professional College of Arts named after K.F. Dankevich, 32, \\ Dvoryanska Str., 65023, Odessa, Ukraine; South Ukrainian National Pedagogical University \\ named after K. D. Ushynsky, 26, Staroportofrankivs 'ka Str., 65000, Odessa, Ukraine 65020, \\ http://orcid.org/0000-0002-8703-9130, e-Mail: evushka1911@gmail.com \\ **Odessa National Music Academy named after A. V. Nezhdanova, 63, Novoselskogo Str., 65000, \\ Odessa, Ukraine, orcid.org/0000-0001-5446-2380, larisa_loboda@rambler.ru \\ ***Odessa National Music Academy named after A. V. Nezhdanova, 63, Novoselskogo Str., 65000, \\ Odessa, Ukraine, https://orcid.org/0000-0002-3003-6472, e-Mail: anatoliy_nosulya@rambler.ru \\ ***Odessa Stolyarsky State Music Lyceum, 1, Sabaneyev Mist Str., 65000, Odessa, Ukraine, orcid. \\ org/0000-0001-7924-2659, e-Mail: olena_kuchma@rambler.ru
}

DOI 10.12975/rastmd.2021928 Submitted October 21, 2021 Accepted December 09, 2021

\section{Abstract}

This article examines the opera music by P.I. Tchaikovsky from the point of view of its Christian orientation as a leading trend in the development of the national opera style of the 19th century and the manifestation of liturgical symbolism in it at different levels of the musical and dramatic whole. Most of the opera compositions of the composer are investigated in the context of the manifestation of iconic elements of Christian culture in them, which is common to Western and Eastern European, with a later branching into two main branches: Catholicism and Orthodoxy. The main liturgical symbols in the drama and musical fabric of opera compositions are highlighted, their gradual increase in each subsequent opera composition by P. Tchaikovsky is noted, in connection with the composer's search for spiritual truths and his appeal to certain subjects, which became the basis for the libretto of opera compositions. The greatest attention is paid to the composer's late operas: "The Maid of Orleans" and "Iolanta", as compositions with the most pronounced symbolism of the Christian cultural tradition. The question of the manifestation of liturgical symbolism at different levels is revealed: from the general dominant idea of the composition, which can be defined as the main line of drama, its deep focus, to more particular ones, through certain dramatic, stylistic, musical techniques and verbal texts, to musical and intonational formulas, intonation stable complexes, which over time received the status of a symbol, a certain sign of a complex expression of the liturgical musical and intonational, verbal and semantic field, became rhetorical figurations, such as "Rest with the Saints" in the Orthodox tradition and "Dies irea" in the Catholic.

\section{Keywords}

P. I. Tchaikovsky, elements of Christian culture, liturgical symbolism, the opera "The Maid of Orleans", the opera "Iolanta" 


\section{Introduction}

At all times, people were attracted by genius, which over the years, or even over the centuries, did not diminish in its importance, but, on the contrary, acquired increasingly more relevance. Such a genius is characteristic of the great Russian composer P. I. Tchaikovsky, whose work, like a magnet, constantly attracts the attention of performers and musicologists. Tchaikovsky in his operas, in most cases, deals with Christian issues. This may not be the main thing in the composition, even barely noticeable, but the presence of the Christian spirit, the spirit of a deeply religious person, is felt in all his work and, of course, in the opera heritage as well. A Christian in spirit and upbringing, looking for the Light of Truth all his life, Pyotr llyich could not but touch upon this topic in one of the important areas of his composing activity. The 19th century was the starting point in the creation of the national opera style, the founder of which was M. I. Glinka and his operas "A Life for the Tsar" and "Ruslan and Lyudmila", where he first used liturgical poetics, becoming a reference point in the development of a national opera school for his followers. We can trace how such liturgical symbols are reflected in the opera composition of P. I. Tchaikovsky as: the Christmas-time symbolic complex of carols (the opera "Cherevichki"), the intonation complex of the Orthodox funeral liturgical tradition (the operas "Mazepa", "The Queen of Spades?), glorification of the feat of Christian love, sacrifice and fidelity to God (opera "The Maid of Orleans"), Transfiguration of man by Divine light in the opera "lolanta". The embodiment of these ideas takes place in different ways at different levels of symbolization (Figure 1, Figure 2).

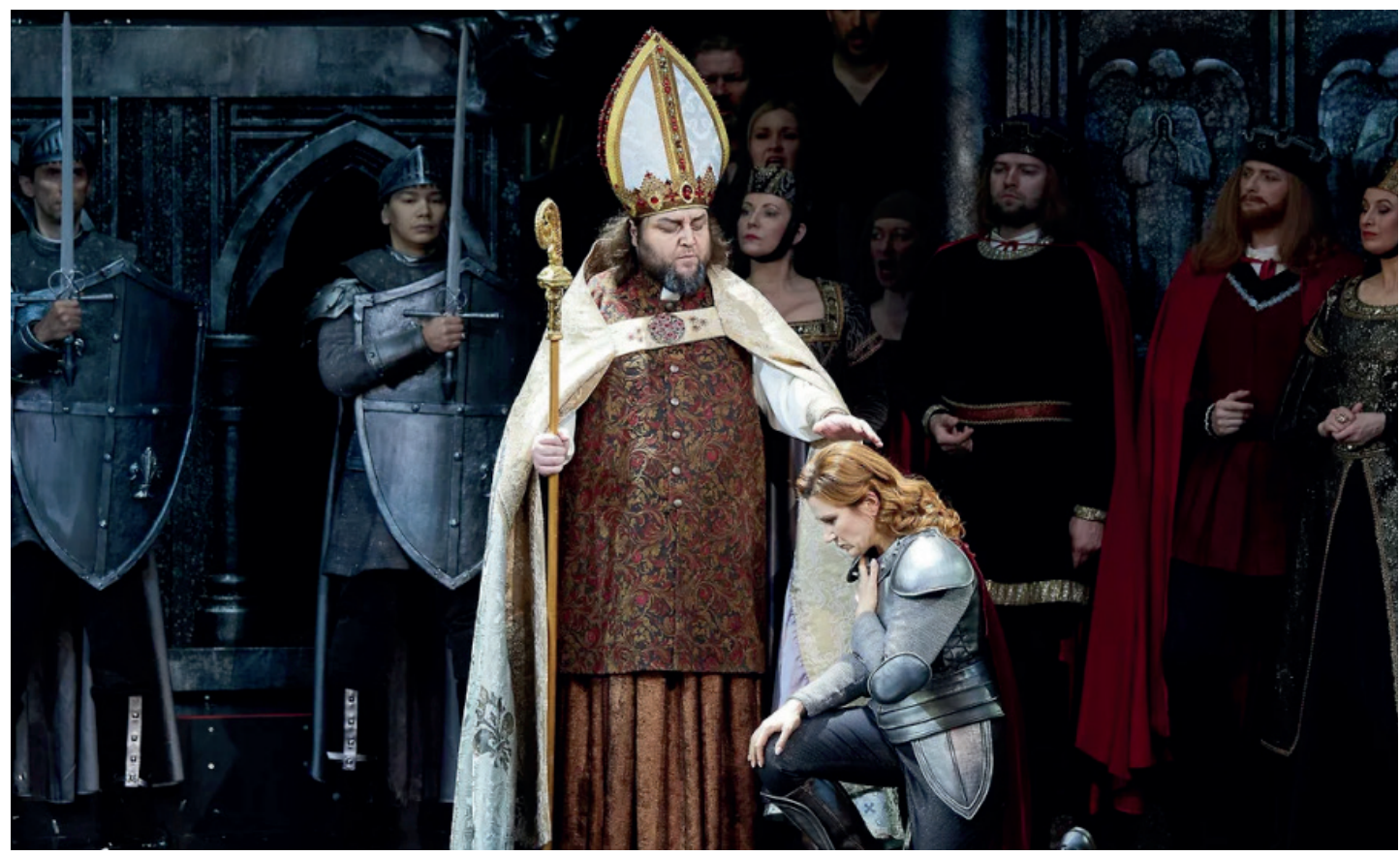

Figure 1. Scene from act 2 of P. Tchaikovsky's opera "The Maid of Orleans". Blessing of John by the Archbishop. 


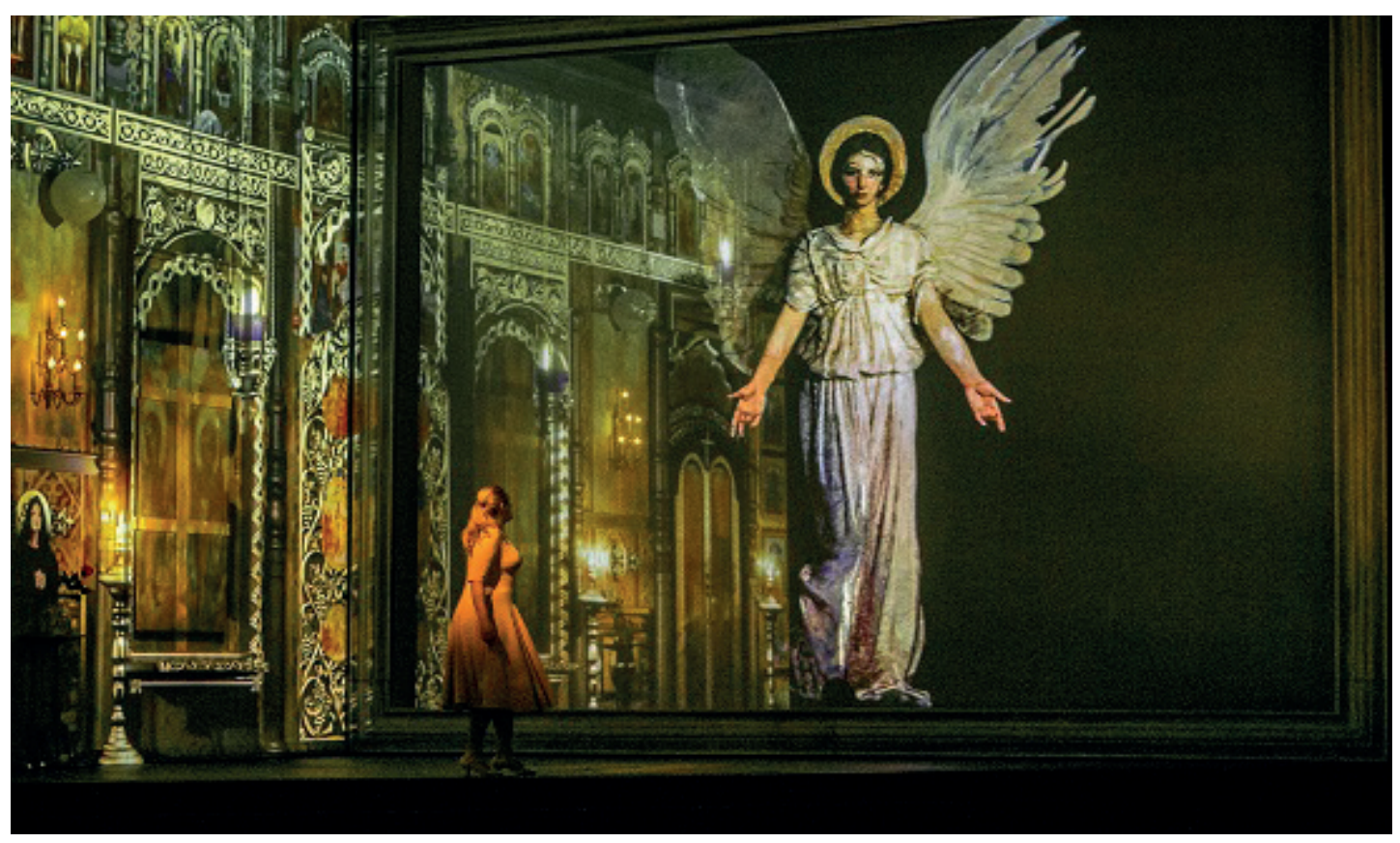

Figure 2. Scene from Tchaikovsky's opera “lolanta” staged by the Mikhailovsky Theater (St. Petersburg, Russia)

\section{Importance of Study}

The scientific novelty of the research lies in the chosen religious and philosophical perspective of understanding the work of Tchaikovsky. Understanding P. Tchaikovsky's work is impossible apart from his views and beliefs, from the era he lived and worked. Undoubtedly, the influence on his music of ideas, traditions, rituals, and the entire complex of social culture of that time, religious and philosophical views, about which the composer himself often writes in his diaries and letters to his close friend Nadezhda Filaretovna von Meck. So in different years, we find the composer's statements about his religious views and philosophical reflections. 1877: "An intelligent and at the same time a sincere believer (and there are a lot of them) possesses such armor, against which any blows of fate are completely powerless" [Tchaikovsky, 2007, p. 99]. In the following letter, we read: " $<\ldots$.. as a result of all my reasoning, I came to the conviction that there is no eternal life. But belief is one thing, and feeling and instinct are another " [Tchaikovsky, 2007, p.102]. Three and a half years later, he writes to Nadezhda Filaretovna: "<...> I feel that I am beginning to be able to love God, which I had not been able to do before. $<\ldots>$ I often pray to Him with tears (where is He, who is He? - I ask him to forgive me and admonish me, and most importantly, it is sweet for me to say to him: Lord, They will be done, for I know that His will is holy. [Tchaikovsky, 2010, p. 523-524].

One of the researchers of Tchaikovsky's diaries Olga Zakharova in her article "Tchaikovsky Reads the Bible" we find the following quote, written by Tchaikovsky on September 21, 1887 “... how much has changed! How strange it was for me to read that 365 days ago, I was still afraid to admit that despite all the 
enthusiasm of the sympathetic feelings aroused by Christ, I dared to doubt his Divinity. Since then, my religion has become infinitely clearer; I thought a lot about God, about life and death during all this time ... "And further" I would like to expound my religion someday, if only in order to once and for all clarify my beliefs and the boundary where they begin the following speculation. But <...> I don't know if I will have time to express the creed that I have developed recently "[Zakharova O. (1990), p. 22-24]. Therefore, it is imperative to study the opera music of P.I. Tchaikovsky from the standpoint of religious and philosophical views, since he undoubtedly expounded his "symbol of faith" in his music and, in particular, in opera works, especially the last creative and life period ("The Queen of Spades" (1890), “lolanta” ( 1891)).

\section{Problem of Study}

The subject of this article is the influence of the composer's religious and philosophical views on his work. Although, there are articles in which the religious views of P.I. Tchaikovsky. Since up to the 90 s of the 20th century, there was a ban (restrictions of an ideological nature in a state with an atheistic model of the world and the USSR). Therefore, researchers were deprived of the opportunity to cover this issue. There was a huge lack of research on this issue without the illumination of which we cannot fully understand the essence of creativity, the origins of melodicism, the drama of the images, and the characters of the heroes of the composer's operas. Tchaikovsky's religious and philosophical views are touched upon in studies of the 21 st century, among which A. Makarova's dissertation research "Mystery prototypes in P.I. Tchaikovsky “, articles by N. Varavkina-Tarasova" Aria of Joanna d'Arc No. 7 from the opera "The Virgin of Orleans" by P. Tchaikovsky: the spiritual symbolism of the canon of repentance during the "test under the sign" and Cherkashina M. Tchaikovsky "The Maid of Orleans": The problem of the genre and the specific treatment of the subject. "But these works do not consider the operatic works of $P$. Tchaikovsky from the point of view of reflecting in them the features of the Christian worldview, liturgical poetics, elements of cult services, allusions to the Sacraments of the Church, the use of musical techniques characteristic of the cult Christian tradition at different levels of manifestation from the general to the particular. , from the idea, the drama of the plot to the melodic intonations and musical techniques.

The subject of this research is the opera music of P. Tchaikovsky, in which, in our opinion, the composer's worldview and the spiritual foundations of his work are most fully revealed.

\section{Research objectives:}

- To analyze the operatic works of P. Tchaikovsky and reveal in them the manifestation of elements of Christian symbolism at different levels of manifestation;

- To compare the drama of operas, its verbal and musical texts with the elements of religious services of the Christian tradition.

\section{Methods}

\section{Research Model}

The study is based on several groups of sources, since its problems go beyond the musical context, joining on the way 
to solve the tasks posed with various areas of humanitarian knowledge. The methodological framework of the article is based on an integrated approach to the research tasks, which includes the methods of historical-stylistic, functional-dramatic, intonationalthematic, semantic and comparative analyzes.

To consider the peculiarities of the religious worldview of Tchaikovsky and his contemporaries, a culturalcontextual approach was chosen, on the basis of which a number of analogies and comparisons were made.

The methodological basis of the work is formed by an interdisciplinary discursive approach to the leading categories of work, as well as textological, semiological, historical-philosophical, genre typological, and analytical musicological methods. In addition, a comparative analytical approach is used in combination with the source method.

\section{Data Collection Tools/Document}

In the study, we rely on original historical narrative sources: diaries, letters, which reflect P. Tchaikovsky's personal thoughts and statements about the importance of religious aspects in the worldview of people of a particular historical era; we study cult liturgical and non-church traditions, elements of liturgical and Christian symbolism, cult holidays and their reflection in the lives of people of this historical era and the music of P. Tchaikovsky, musical texts of operas by P. Tchaikovsky ("Voevoda", "Mazepa", "Cherevichki”, “Undine”, "The Queen of Spades", "The Maid of Orleans" , "Iolanta") in the context of reflecting the composer's religious and philosophical views.

\section{Findings and Argument}

\section{Theme 1. Spiritual vector of $P$. Tchaikovsky's work}

Religious ideas, which are rooted in childhood, the search for God and Truth, issues of life and death, life behind the grave, which worried Tchaikovsky all his life, occupy one of the main leading directions in his work. The composer grew up in the atmosphere of an Orthodox family. Among his maternal ancestors, there were clergymen. His godfather and at the same time a teacher of the Law of God and the Russian language was a teacher and ethnographer, archpriest of the KamaVotkinsk Annunciation Cathedral Vasily Yegorovich Blinov. Tchaikovsky gained experience and knowledge of musical church life at the Imperial School of Jurisprudence, where there was his own house church. During his nine years of study, Tchaikovsky sang in the school choir under the direction of the outstanding choir director, remarkable choral conductor and composer Gabriel Yakimovich Lomakin. In a letter to the Baroness N. F. von Meck from November 24-25, 1879, Tchaikovsky wrote:

"When I was a boy, I had a splendid soprano voice, and for several years in a row I sang the first voice in a trio, which is sung by three boys in the altar in the episcopal mass, at the beginning and at the end of mass. The Liturgy, especially during the episcopal mass, left on me then... the deepest poetic impression" (Tchaikovsky, 1879).

Tchaikovsky attended and loved church masses. 
"I go to Mass very often; the liturgy of John Chrysostom is, in my opinion, one of the greatest works of art, <...> oh, I love all this so much, this is one of my greatest pleasures!" he wrote to N. F. von Meck on November 23, 1877 (Tchaikovsky, 2007, p. 101 - 102).

\section{Theme 2. Christian cult tradition} and features of its manifestation through various elements of liturgical poetics

Liturgy is a complex sacred-symbolic action, in which there is an external, visible symbolic side with illustrative symbolism (a sequence of certain prayers, singing and sacred acts that signify the "essence", or the spiritual meaning of worship) and an internal, hidden from the eyes of the uninitiated, mystical (mysterious) side that is invisibly transubstantiated at divine masses. The rite, as the outer side of the Liturgy, has its own symbolism, which is expressed through words, music, the art of fire, smoke (incense burning), through icons, architecture, and jewelry craftsmanship. The synthesis of arts inherent in temple action is also one of the characteristics of opera art that emerged from the depths of history sacred performances on mythological, legendary, religious subjects, which allows composers to use in opera work many elements that make up worship (chorality, elements of church tunes, intonation formulas, plots from the Gospel, textual allusions, genre modifications, the principle of performance, etc.), giving them theatricality, entertainment and bringing Christian ethics and dogma to the broad masses.

"The main way to penetrate the sacred space of worship is prayer, the various forms of which form the spiritual fabric of worship", wrote Father Alexander Schmemann in his Introduction to Liturgical Theology (Schmemann, 1996, p. 27).

Therefore, the main genre variety that refers us to liturgical symbolism in an opera composition is the genre of prayer. For Tchaikovsky, this genre also occupies one of the main places in operas with a Christian orientation.

\section{Theme 3. The manifestation of} elements of Orthodox culture in the operas "Voevoda", "Ondine", "Cherevychki"

In the composer's first opera based on the play and on the libretto by A. N. Ostrovsky "The Voyevoda" ("ADream on the Volga"), behind the plot of love twists and turns, the Christian virtue of gratitude to God and the tsar, as the anointed of God, is discerned. This third act of the opera illustrates, where in the final chorus the actors who are on stage at this time thank God and praise the tsar for wisdom and mercy, in which the conciliar unity of the people and the devotion of Orthodox souls to God and the tsar, as the anointed of God, are manifested.

Despite the fact that in the opera "Undina" on a medieval plot based on the fairy tale of the era of romanticism by the German writer Friedrich Heinrich Karl de la Motte, Baron Fouqué, there is much magic, Christian symbols can be traced in it as well. The main character, Undina, is a soulless creature endowed with whimsy, rebelliousness, selfishness, gaiety, willfulness, when she finds a soul, she becomes kind, obedient, loving, suffering, forgiving, like a lamb without complaints. She respects the Creator 
God, sends to Him prayers together with people, willingly accepts the sacrament of the wedding. The main character traits of Undine are Christian virtues forgiveness and sacrificial love.

In the opera "Cherevichki" based on the novel by N. V. Gogol's "The Night Before Christmas" with a comic-fantastic plot, the composer, along with genre pictures of folk customs and rituals, weaves into the plot of the opera features of Orthodox life. Pyotr Ilyich, who often visited Ukraine, knew well the culture and life of the people who lived here: he was attracted by the melody of local folklore, traditions, rituals, nature. The opera makes extensive use of the tradition of Christmas singing outside the temple singing carols, an example of which is the chorus from the first act of the seventh final scene ${ }^{1}$. The genetic memory of the joy of the national holiday, national traditions in the coverage of one of the main religious events the Nativity of Christ, echoes in the soul of any person who grew up in the traditions of Christian culture, in the tradition of performing spiritual cants.

In the third act, the third scene, number 19, which the composer called "Polish", musical means depict the palace of the Tsarina, seeing which Vakula, in delight, says: "Was I not transported to heaven! And do not I see this miracle in a dream?" The palace is perceived by

1 Boys and girls sing carols alternately for male and female choirs (antiphonic singing technique). In the carol, God is glorified: Chorus of boys (behind the stage, not far away): "There walks, walks a moon across the sky. Glorious art thou, glorious art thou, / Good God in heaven!» The girls answer them "Quietly angels flew from the sky / A sweet song they pure sang / A clear star shone high / I saw the little star of the Holy Child!» (Tchaikovsky, 1940, p. 84-86) him as a paradise, a wonderful place, and the empress herself is characterized by the words put into the mouths of the courtiers ${ }^{2}$. Attention is drawn to the words "Behold, the wife is coming", which are very consonant with the words of the troparion of Holy Week of Great Lent (it is sung at Liturgies on Holy and Great Monday, Tuesday and Wednesday) "Behold the Bridegroom is coming in midnight", which refers us to the image of Christ. The word "scarlet robe" also relates the image of the Queen to the image of Christ, meaning the clothes in which the royal faces were dressed, and we also read in the Gospel of John:

"And the soldiers weaved a crown of thorns, put it on his head and clothed him in a scarlet robe" [Jn. 19:2], which indicates that the "scarlet robe" was worn on Christ. But we see here a clearly existing contradiction the music and the whole situation testify to something else the tsar's power departed from Orthodox roots, a foreign woman with a foreign culture is in power, which in the opera and in Gogol's story is shown as a fantastic, fairy-tale character, that is examined in detail by Y. Sitarskaya (2016).

The fourth act of the opera begins with an imitation of the people's cry in the roles of Solokha and Oksana.

"The vocal parts of women who cry, contain chromatic moves in the melody, move in parallel seconds, converge

2 Hooray! Hooray! Let the queen live!

Sing, strings, sing, yarn,

The seed is coming to the throne;

Wears scarlet robe

Wisdom into power, into law.

Glory to your days, queen,

The ringing will immortalize the lyre. 
in unison, sometimes as if mixed in disorder all these are characteristic features of common lamentations in everyday life" (Labik, 2017, p. 29).

Most likely, the composer recreated an element of folklore that he could hear when visiting his cousin in the village of Kamenka, Cherkasy region. The ceremony of mourners at funerals, of course, belongs to the pagan tradition and has little to do with the Christian idea of death as an assumption. However, this technique in opera helps to highlight the joyous character of Christian Matins.

The finale of the opera begins with a festive ringing the gospel. The people leave the temple during the chime, inviting each other to come there. The main character Vakula, about whom we learn from Gogol's story that he is a God-fearing man, who embodies the best features of a Ukrainian guy that is not afraid of the devil and can win and overcome everything, is the image of a hero, talented, versatile (Vakula is a blacksmith and painter, artist), and a devoted person, wooing Oksana, will say to Chub: "To you, father! Do not be angry, for the feast of Christ, have mercy! <...> I confess, in everything, in everything I repent of, I am guilty, I am guilty!", to which Chub replies: "Well, that's it, that's it, stand up! Let's forget what happened between us! I forgive, so be it, I forgive you...". In Orthodox Russia, there is such a custom, for the sake of a great holiday and the name of Christ, they pardoned and forgave debtors, forgot the quarrels. After the blessing of the young, in the final choir in the wedding ritual song, the wish is heard not only to the young, but also to all God's people "Good day!" The hymn solemn sublime music affirms the coming of Christ, the reign of light and virtues. Tchaikovsky thereby draws our attention to the temporal space in the opera.

It begins with the evening, with a dark night, continues on a bright sunny morning and ends with a wish of a good day! Thus, we see the liturgical circle, which begins with Vespers and ends with Liturgy, the culminating mass of the Christian tradition, which also confirms the presence of elements of Orthodox culture in this opera composition.

\section{Theme 4. Cult symbols-formulas in} the operas "Mazepa", "The Queen of Spades"

The music of the Orthodox and Catholic liturgy gave secular music samples of rhetorical figurations that are easily recognizable and are already symbolic formulas. These are such chants as "Thy Cross do we adore, o Master", "Cross is the guard of the Universe" by A. Arkhangelsky, based on the ascending rhythm, the singing of the sounds " $c$ " and " $d$ ", the iambic character of the text, "With the Saints, give rest", where a small-second descending and thirds ascending intonation is perceptible, which resembles the Latin "Dies Irae". The intonation complex of the Orthodox funeral and memorial liturgical tradition can be found in the opera "Mazepa", namely, the pre-dying prayer in the scene of the death penalty of Kochubei and Iskra, where the choir picks up the words of the prayer, which, as A. Makarova notes in her research, referring to I. Lapshin,

"is based on the style of liturgical chants of the Orthodox Church, mainly from the funeral rite. The development of prayer from a solo statement to a 
choral one turns it from Kochubei's personal farewell to life into a religious and philosophical understanding of not only the ongoing tragedy, but also the sacrament of death in general" (Makarova, 2017, p. 140-141).

In "The Queen of Spades", the sound of the choir of singers in Scene V carries a great psychological and emotional load this is both a picture of Herman's hallucinations and the voice of another world that prepares the appearance of the Countess's ghost. In the finale of "The Queen of Spades", the funeral prayer of the male choir of players sounds, who ask to forgive and reassure Herman's rebellious and tormented soul:

"Lord, forgive him and repose his rebellious, tormented soul" (Tchaikovsky, 1911 , p. 50 t. $10-18$, p. 745).

\section{Theme 5. The embodiment of the} sacred nature of Joanna's mission in the opera "The Maid of Orleans" In the opera "The Maid of Orleans", Tchaikovsky, in the form of a heroine girl, embodies the idea of Christian love, sacrifice and loyalty to God, where throughout the opera the heroine herself and her entourage often turn to the genre of prayers (supplicatory, hymn, thanksgiving, augmented), to biblical vocabulary (dove, sickle and harvest, lamb and flock), elements of sacred symbolism (sword, banner of a certain color) are interspersed into the existing plot, which also adds features of the mystery genre to the opera. By carefully following the plot of the libretto, one can find certain correspondences and closeness to the events of the Gospel. John's prayer near the "secret oak" before the final acceptance of the mission sent down to her recalls the events of Holy Week, when Christ, after praying for the Chalice in the Garden of Gethsemane, voluntarily sacrificed himself for human sins. The beginning of the chronological coincidence of events "Yes, the time has come!" (in the opera, the first aria of Joanna) recalls the story from the Gospel about the Gethsemane prayer, which is close to the words: "Look, the hour has come" [Matt. 26:45], "Enough! The hour has come" [Mk. 14:41], "Father, the hour has come" [Jn. 17: 1]. There is the pass from doubts and indecision "let the bitter Chalice pass by" (Tchaikovsky, 1979, No. 8 "Final”; p. 111 , c. 70, t. 2), to the acceptance of the Divine will and his mission "may the will of the Lord be done" (Tchaikovsky, 1979 , No. 8 "Final"; p. 126 , c. 130 , t. 4-5). In the Gospel: "Father, the hour has come..." [Jn. 17: 1], "My Father, if it is possible, may this cup be taken from me" [Matt. 26: 39], "yet not my will, but yours be done" [Lk. 22:42]. N. VaravkinaTarasova comes to a similar conclusion, analyzing the image of Joanna and her first aria in the opera No. 7 from the point of view of the level of liturgical awareness of life events, a story in the name of God, who, by the greatness of her spirit, transformed her from a simple girl into a Warrior-Savior. In her opinion, Joanna and her dramatic line are a monoopera of the Spirit within the whole opera, and the main spiritual meaning of the aria is "liturgical this is the canon of repentance, with its severity, inner composure, unshakable focus on the expected Divine communion, submitting to the will of the Spirit" (VaravkinaTarasova, 2018, p. 27).

The similarities and parallels with the Gospel stories add a mystery character 
to the opera, emphasize the blessed sacred nature of the mission entrusted to the main character, Joanna, and also refer us to the reading of the Gospel at masses on the first Sunday of Great Lent.

The wide inclusion of prayers in mass scenes and in the texts of Joanna, although they are not canonical, but created by the composer himself, helps Tchaikovsky to display the stages in the relationship of the people with God, and build them from liturgical requests for mercy to a thanksgiving moleben ${ }^{3}$, to a hymn of praise to Him. The composer's appeal to the genre of prayer helped to create a special religious and spiritual level of the composition. As Makarova notes in her research, the events in the opera are similar to the description of the way of the cross and are built by the composer on the dramatic principle "from prediction to accomplishment", which is characteristic of the mystery genre (Makarova, 2017, p. 16). The events predicted by Joanna at the beginning of No. 5 ("The Savior is alive, he is coming in power") also begin to come true in the congregational prayer, that is written by juxtaposing the ensemble of soloists and the choir (antiphonic method), which in its stylistic, musical, and linguistic features is close to the liturgical genre in the form of an augmented litany (requests are repeated, and the choir joins the requests of the ensemble of soloists), the people, together with their savior, ask the Almighty: "King of the Highest Powers, you are our Cover, our Hope, have mercy on us and look down on us from above! Give peace to our country, struck by your anger again, give us victory over the evil enemy!" (No. 6). One of Tchaikovsky's favorite techniques 3 Moleben is a short mass in which people ask God for health, prosperity, and also thank God for all His mercies. is used here: the penultimate measures of the chorale sound acapella (Tchaikovsky, 1979, scene no. 6, c. 90, p. 95-96), which is one of the features of the Orthodox liturgical singing practice.

One of the characteristic features of the opera "The Maid of Orleans" is that Tchaikovsky uses here an intonation close to Catholic chants, the choral and individual prayers written by him contain features of both Orthodox and Catholic masses. Thus, in Act III (No. 20) the sound of the organ is introduced, and in No. 23, the choir of monks, the only original text of the Catholic prayer "orate pro ea" (pray for her) is used, which in its genre is close to "the liturgical prototype of the church supplicatory prayer" (Makarova, 2017, p. 96).

The aria of Joanna, which says goodbye to her beloved and dear places, where, in communion with nature and purity, she cognized God, accepted His will, sounds very touching. She hears Angels who cheer and comfort her, pass on the conditions of the covenant with God that higher powers will help her free her native land and return the throne to her rightful heir, but she needs to become Christ's bride, preserve her chastity, purity of soul and a heart free from earthly passions... Joanna's address to people, her consolatory speech, reminiscent of a sermon, turns into a common prayer-hymn "The King of the Powers above" (Cherkashina, 1994, p. 180). Such a general dramatic line brings the opera "The Maid of Orleans" closer to the opera by M. I. Glinka "Life for the Tsar", in which idea of conciliarity, the selfless sacrifice of Christian love in the name of the Tsar and the people, the belief that the royal power from God closely interacts with each other. 


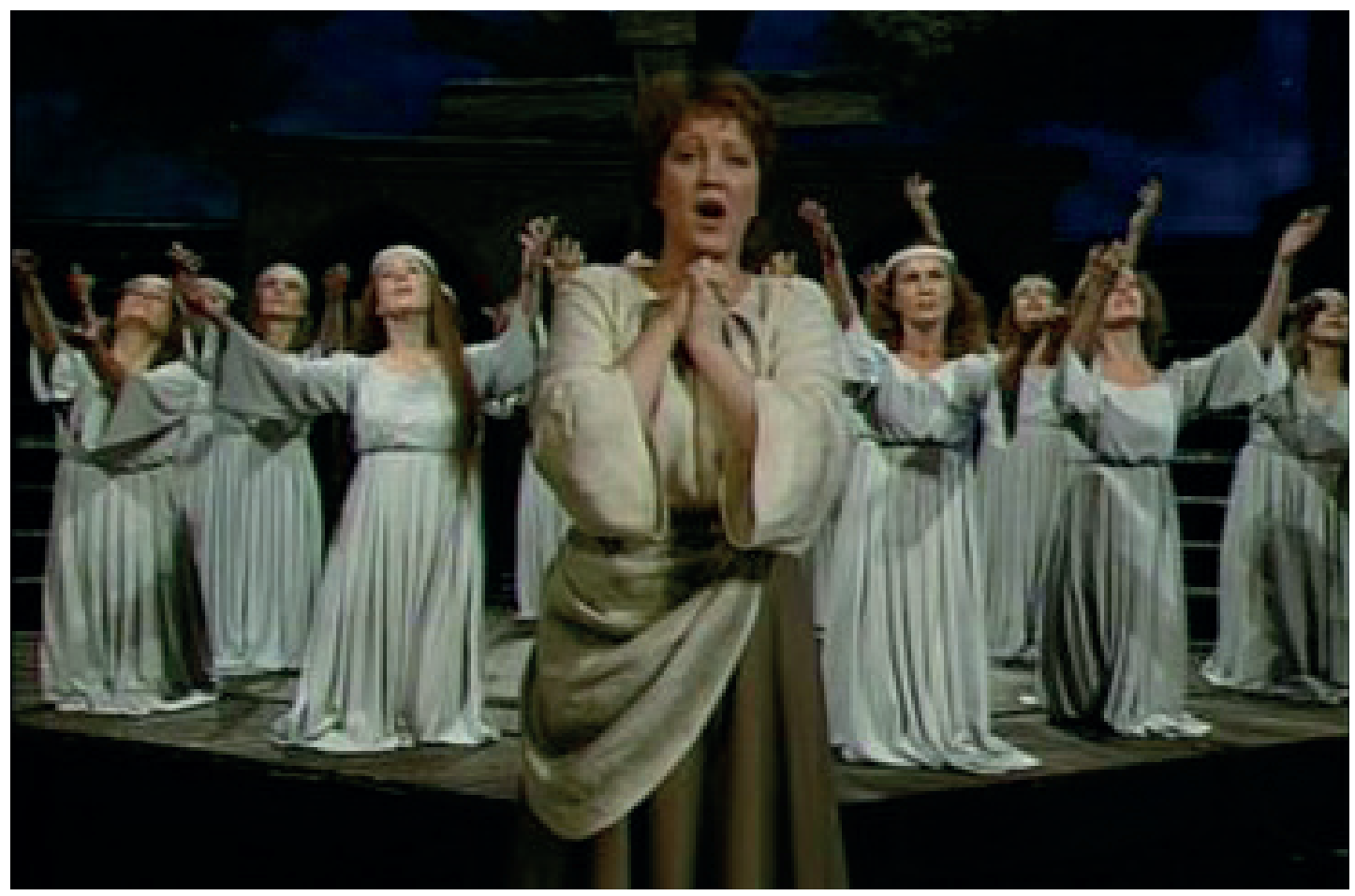

Figure 3. Prayer "The King of the Powers" from act 1 of the opera "The Maid of Orleans" by P. Tchaikovsky

Joanna's choice of God is confirmed by her victories in battles, her story about the meeting with the King, about how the Blessed Virgin appeared to her at night prayer for three nights and told her to take the sword and the banner, defeat the enemies of her people and bring the anointed one to Reims, and crown him with the crown (Tchaikovsky, 1979, p. 233-234). At the behest of the Mother of God, Joanna sees the heavenly world. Tchaikovsky's image of Joanna is a conductor of divine prophecies from the Purest Virgin about the fate of the French state, which we hear in the first act No. 5 and in the story of Joanna from the second act. These fragments are saturated with the Gospel vocabulary, which correlates the plot of the libretto with the events of sacred history, indicates the difficult path of the cross to the salvation of the soul.
In the musical score, in order to consolidate the sacred character of the composition, to support prayer, Tchaikovsky uses his favorite technique, chorality, and not only in the part of the chorus, but also in the orchestration; he uses the general ascending intonation of the hexachord from V to III degrees of the major, which allows defining this element as the "leit-intonation of prayer" (Makarova, 2017, p. 98). It should also be noted that the presence of the sacred sphere is displayed by the composer with the figurations and arpeggios of the harp, as well as by the reproduction of ringing intonations in the orchestra: the roar of the timpani, creating a dominant organ point, against the background of which the chorale of brass sounds and passages of strings, with an increase in rhythmic pulsation, create the effect of bell chime similar to 
the sounds of mystical bells announcing to Joanna a meeting with heavenly powers (Makarova, 2017, p. 117).

\section{Theme 6. Martyrdom as an}

\section{Element of Christian Culture}

The intrusion of the Choir of Angels into the love duet of Lionel and Joanna: "The covenant of heaven has been broken, you are sinful, you cannot complete the holy work. You must atone for your sin with patience, do not be afraid of torment, suffering is fleeting, and captivity, and death, endure as redemption, bliss awaits you in heaven!" (Act four, No. 22, c. 220, 230) (Tchaikovsky, 2017, p. 413-415), as if dividing space into two worlds the real world and the sacred. Overcoming the temptation of earthly love with the help of the intervention of heavenly forces, Joanna accepts martyrdom, which is the Christian concept of deliverance from sin through the participation of the power of God and obedience to His will: "Heaven told me the truth: there is no struggle in my soul, fate showed me my way, and I must submit to it" [No. 22, c. 259, 260, p. 418]; "The Lord orders me to win the gusts of passionate excitement, whether I break His orders, can I ruin my soul?" [No. 22, c. 280, 290, p. 419-420]. Joanna conquers her earthly flesh and love for the salvation of her soul. The heroine's martyrdom is the highest sacrifice that can be made. Here one can hear "the motive of heavens that have opened a symbol of the highest reward in eternity", "the motive of heavenly bliss as a result of redemption" (Makarova, 2017, p. 91).

The composer brought the martyr end of the heroine's journey of the cross to the idea of the atoning sacrifice, referring us to the memories of Christ's atoning sufferings. Of course, the difference between them is incommensurable Christ is sinless and atoned for the sins of people with His Sacrifice, and Joanna is atoned for the covenant she had broken with God. However, this makes it possible to talk about the liturgical line in the opera the offering of sacrifice in the name of the purification of the soul and the act of thanksgiving to God for the shown mercy and the possibility of salvation for life in eternity. The inner state of the Maid of Orleans, who is being led to execution, Tchaikovsky reveals in short remarks that continue the line of connection with a passionate plot and can be correlated with the description of the Savior's feat on the cross by the evangelists: "Holy Father! Oh, support me, I'm scared!" [No. 23, c. 60, v. 9-10, p. 450] recalls the words of Christ on the cross when He turns to His Heavenly Father: "My God, my God, why have you forsaken me?" [Mk. 15:34]. Also, the last prayer of Joanna, which was introduced by Peter Ilyich, "Lord, receive me into your monastery" [No. 23, 3 bars to c. 120 , p. 458], echoes the dying cry of the Savior "Father, into your hands I commit my spirit" [Lk. 23; 46, p. 210].

The choral scenes that permeate and fill the opera space of this composition are built by the composer on the basis of introducing the genre of prayers into the linguistic and musical fabric, which makes it possible to classify this opera as a sacred type of opera, where prayer, as a direct appeal of persons to the Absolute, is one of the main components. This is also noted by Makarova, who emphasizes that in the opera, out of twenty-three numbers in fifteen we find prayers, and this is more than half of the 
opera numbers used appeals to God and heavenly forces (Makarova, 2017, p. 95). This dramatic technique is used by the composer to emphasize the separation and inseparable unity of two worlds the real earthly and the highest spiritual sacred world, through the intervention and assistance of which all fateful events on earth take place.

\section{Theme 7. Enlightment with Divine} Light - the Eucharist of the Soul "lolanta" is the quintessence of P.I. Tchaikovsky

"Iolanta" is the last opera of the great composer. It became the brightest in the creative heritage of Tchaikovsky. The over-Idea of the opera, its main "hero" is Divine light, a plot with a happy ending, in which God's mercy is manifested, where the darkness of the flesh is overcome by the victory of spiritual light, and the whole opera is filled with love. With this opera, the composer supposedly sums up not only his creative life, but also his inner, spiritual life, his hesitations and searches for God.

At the heart of the opera, there is the sacred thought about the Transfiguration of a person, about Divine Epiphany, healing with spiritual light "on those living in the land of shadow of death" [Matt. 4:16; L. 1:79], thanks to which there is Communion with the Creator, the Creator of all goods. This is the quintessence of Tchaikovsky's attitude to the gospel idea of divine love and mercy "Come to me, all you who are weary and burdened, and I will give you rest" [Matt. 11:28], which became the basis of the composer's worldview in the second half of the 1880s - 1890s.

The entire composition of the opera was constructed by Tchaikovsky in such a way as to fully reflect the soul's striving for light from the dull darkness of ignorance and nescience. The orchestral intro is entrusted to the woodwinds these are the descending, groaning moves of the "suffering motive". G.A. Pribegina calls the introduction a portrait of lolanta herself and the groaning move "the motive of blindness" (Pribegina, 1983, p. 165), which will appear in different variations in the opera later. With the development of the action, this motive is repeated, intertwining with the intonation structure of Vaudemont's part, which is the first to make it clear to the heroine what exactly she lacked for the fullness of life. The finale of the opera is a bit like the Sacrament of the Eucharist, where the main character participates in the "Communion" with God's glory, with God's Light, which is "the best pearl of his crown!" (Tchaikovsky, 1987, p. 138 , s. 420 , t. 10). In general, in Christian philosophical thought, a person is viewed as an integral personality, carrying two aspirations in himself the earthly, which marks a horizontal plane, and the heavenly, reflecting the vertical aspiration of the spirit:

"Both of these lines, expressing the two main directions of life aspiration, are a flat line, or horizontal, and ascending, or vertical, are crossed. Since these two lines represent an exhaustive image of all possible life directions, their crossing the cross is the most universal, accurate schematic representation of the life path", wrote E. Trubetskoy (2011, p. 78).

The cross symbol is universal. It is present in all areas of culture and, as we know, is often used by composers from different 
countries, eras and religious teachings. This symbol, of course, reminds us of the way of the cross of Jesus Christ, that a person was crucified in space and time circumstances between the earthly horizontal and the vertical of Heaven, suffering and daily overcoming the eventual circumstances of his life, each person goes his own way of the cross, choosing a vector and the goal of his path. In "Iolanta", all the heroes are positive, there are no external conflicts, however, the inner struggle of the main character for the opportunity to see the light of Divine Truth leads to a powerful catharsis in the finale of the opera.

\section{The sacred space of the opera}

The space where the main character lolanta is located is not just a garden, it is "paradise" (a word that the librettist constantly uses), it is a fusion of the sounds of the surrounding nature with the sounds of heaven into a single solemn choir, where the scent of flowers evokes a "blissful sweet dream" where all torments and doubts are forgotten. The chorus of servants lists the flowers that they have collected at the request of Iolanta in the garden; there are nine of them, and they all cannot bloom at the same time (buttercups, lilies of the valley, cornflowers, mimosas, roses, levkoy, lilies, balsamines, jasmine) that also makes it possible to say that the garden is extraordinary, mystical. The lullaby completes the creation of the image of a special sacred scene, which resembles the garden of Eden, which is guarded by an angel with a fiery sword (in the remarks to the opera's plot, there is an inscription at the entrance, which prohibits entry to "paradise" "on pain of death"). The garden, with the transformed nature in it, is a book of the Creator's knowledge for lolanta, as "The Invisible and Good God" is a natural genre feature of the mystery, the action of which is placed in a sacred chronotope" (Makarova, 2017, p. 149). In the words of Marta's nurse, Modest llyich puts the text "From Heaven, the Lord of the Universe will look at you" (Tchaikovsky, 1987, p. 36 , no. 3 , c. 60 , t. 9-14), and in the part of Brigitte and Laura we also hear there: "God, listening to the prayer of a child, will send to the earth happiness, joy, peace and quiet to the earth with a generous hand". This is a direct allusion to lolanta's prayer communication directly with God. It should also be noted that lolanta directly addresses the Creator, as a person who really exists: "Good, Great, Unchanging, in the darkness you showed yourself to me! Let me now, Creator of the universe, know you in the light of day!" (Tchaikovsky, 1987, p. 190, p. 197-198). All the characters in the opera call lolanta "dove", "pure angel”. From other epithets that were inherent in the heroine of the story, Modest Tchaikovsky refused, thereby emphasizing the light spirituality of the image of lolanta he created. Most of all, the image of lolanta is revealed in Vaudemont's romance (No. 6-a, inserted), which was written after the completion of the entire opera. The romance reveals Vaudemont's dreams of an ideal lover, which are born in his imagination in the form of a half-sleephalf-vision "Immersed in midnight peace, love in me, dreaming, sleeps" (Tchaikovsky, 1987, No. 6-a, p. 92-93, p.10, t. 3-6). Adjectives such as "blameless", "cherubic", the noun "benevolence" are borrowed from the Church Slavonic language and are very reminiscent of the texts of prayers, which are written in honor of the Mother of God. 
The image of the Moorish doctor AbnKhakia, created by the librettist, is the one who carries the Truth, is the conductor of the Divine Providence for bodily and spiritual insights, is the one who is called and wants to cognize God and introduce those who wish to cognize such knowledge: "And before opening to the light fleshly mortal eyes, we need this feeling for the eternal soul. When the consciousness of the great truth appears in the mind, then it is possible that desire will awaken light in bodily darkness" (Tchaikovsky, 1987, p. 69, p. 40, t. 10, p. 50). His secret knowledge through certain mystery rituals that resemble initiation ("the feast of dedication"), although this is not openly discussed in the libretto, leads the blind lolanta to the Epiphany that resembles the Epiphany in the spirit. It is also possible to compare this act of healing lolanta with death and resurrection. In connection with this comparison, lolanta's dream with No. 3 with p. 30 can be interpreted as dying, and the awakening of the heroine and the meeting with the knight, as the awakening already in another mysterious dimension.

Iolanta's readiness to endure any torment for the sake of saving the life of a dear person ("Name the torment, suffering, pain: oh, to save him, I can resignedly take it all down" (Tchaikovsky, 1987, p. 150 , v. $8-10$, p. 164) brings the plot of the opera closer to the Passionate plot of passion, but not fully. Even though hints of a passionate plot appear in the words of King Rene, who compares the main character with the Lamb of God: "Like the lamb of God, she goes to torture. My God!" [p. 210, v. 9-11, p. 172], in the words of Bertrand: "It is finished!" [Jn 19:28] <...> Like a lamb calmly and firmly, like a rock she sat, our dove" [p. 120, v. 7 , p. 186; p. 130, v. $2-3$, p. 187]. But all this is very far from the suffering of the way of the cross, there is no end of the lives of the heroes with martyrdom. Here we see that the words "It is finished!" is used to convey the mood of the completed treatment, as the achievement of a new level in the knowledge of the world.

The genre of prayer as one of the main ones in the opera "Iolanta"

In the text of the opera, the librettist created a whole complex of prayers or allusions to prayer. So, for example, Bertrand, having learned about the death of his friend the squire Raoul, complaining about his death, offers a short prayer that the Lord would rest Raoul's soul: "Send, Lord, to his soul some peace!", using the ascending movement of the melody as an appeal to God. This measure was written by the composer acapella, which immediately gives our experience a reference to the Orthodox funeral mass at the Liturgy. Aria-Prayer of King Rene contains the motive of repentance for some serious sin, which, according to Rene, led to his daughter's blindness. Tchaikovsky's opera does not speak of the cause of the heroine's blindness, while Miller and Zotov's translations speak of an accident that resulted in blindness (Hertz, 1883; Hertz 1850). The librettist and composer, on the other hand, with the initial phrase of the Arians allude to the Gospel story about the blind from birth, when the disciples ask the Lord: "His disciples asked him, "Rabbi, who sinned, this man or his parents, that he was born blind?" [Jn 9:2]. Let us compare with the first phrase of Rene's aria: "My Lord, if I am 
a sinner / why does a pure angel suffer? Why did you plunge into darkness because of me / do you have her radiant gaze?" (Tchaikovsky, 1987, p. 120, v. 7-10, c. 130 , v. $1-5$, p. 59,60$)$. In fact, from this moment on, the librettist consistently draws associations with the plot of the gospel story. The text of the aria itself is a supplicatory prayer. In the finale of the opera, when the Glorious Hymn to the Creator will sound, in Rene's words there is gratitude to God for having heard his request, for mercy and healed his daughter: "You heeded my tearful prayer, Lord!... You took your slave from the mirk of darkness!" (Tchaikovsky, 1987, p. 230, t. $3-7,9-10$; p. 240 , t. 1, p. 206-210), "Creator! For this moment, take the rest of my life!" (Tchaikovsky, 1987, p. 140, t. $3-5$, p. 190) are prayers of thanksgiving.
The choir in the opera is the protagonist: the maids and girlfriends of the main character, who sincerely sympathize with her grief, worry about her, about her fate. Thanks to the choir, there is a feeling of a liturgical action, when the replicas of the main characters evoke a prayer response from the choir. The reception of antiphonic singing is clearly seen in the final chorus. Words and theme "Hosanna in the highest!" first are sung by the soloists, then in the choir, and it is repeated again for the soloists, the choir answers them and at the end a congregational prayer sounds: "You are the Brightness of the Light of Truth, Glory, Glory to You, God Almighty! Praise to You!" (Tchaikovsky, 1987, from p. 250 , t. 1 , p. 215 to the end).

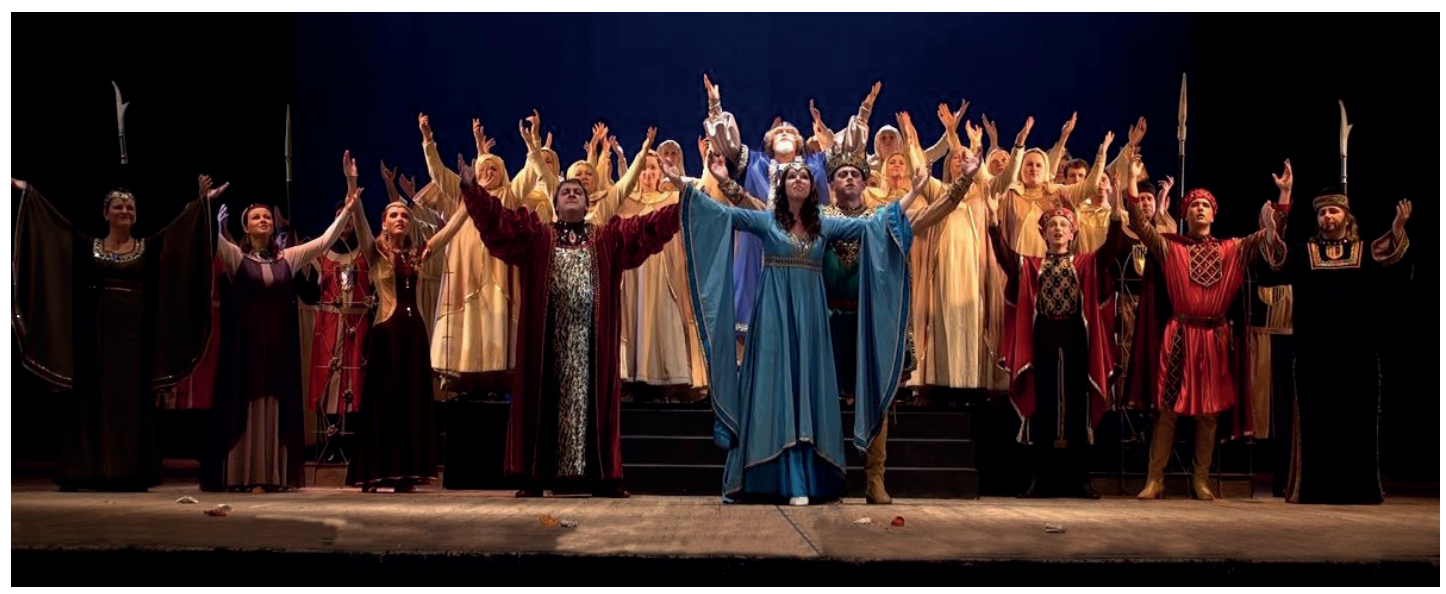

Figure 4. Final scene "Praise to the Creator, the giver of all blessings, praise to the Creator!" from Tchaikovsky's opera "Iolanta".

The finale of the opera as a result of the composer's religious and philosophical ideas

In the finale, all religious and philosophical ideas are concentrated, all lines of development are brought together into a single hymn of praise. The atmosphere of the miraculous, the creation of a mystical sacred place "garden-paradise", indications of the gospel stories about the blind from birth and Passionate events, the idea of salvation, which is carried through the whole plot, choral and solo prayers, in which there is a liturgical subtext, all this gives reason to say that the opera "lolanta" is close to the genre of Proverbs 
with features of symbolist mystery, in which the main idea is to overcome a cruel fate through the knowledge of Divine Providence. The final scene concentrates all the liturgical elements scattered in the musical and verbal texts of the opera. The text of the finale itself is a personal and congregational prayer of thanks: "Praise to the Creator, the Giver of all blessings, praise to the Creator!" (Tchaikovsky, 1987, p. 220, t. 4-7, p. 203). Each character in the opera praises the Creator, focusing on His different qualities. Iolanta is like an uncomplaining slave who feels her smallness, because before the Lord there is a host of blessed people and Cherubim. In our opinion, the author completes the storyline of each of the characters with own logic and role, emphasizing the individuality of each and the similarity that unites all people, like the creation of the Lord into one whole. Therefore, the final words sound from the lips of everyone, like a single prayer, a single praise to the Creator (with one mouth, one heart $)^{4}$.

In general, the text of the choir, which ends the opera, resembles the prayers that are sung at the end of the Liturgy "We have seen the true light" and "Let our mouths be filled with Your praise!" and in connection with the composer's emphasis on the timing of the action, it can be assumed that this is indeed the end of the Liturgy, which closes the daily liturgical circle.

4 «Receive the praise of us, submissive slaves! In dust we are in front of you! Glory to Thee, Almighty Creator! Hosanna in the highest! Hosanna in the highest!

You are the Light of Truth, Brightness, Glory, Hlory to Thee, God Almighty! You are the Light of Truth, Brightness, Glory, Hlory to Thee, God Almighty, Almighty Creator! Praise to You! Praise to you!» (Tchaikovsky, 1987, p. 211 - 222).
Theme 8. Liturgical symbolism of Tchaikovsky's operas at different levels of manifestation

Thus, in the operas of Tchaikovsky, liturgical symbolism is manifested at all three levels. The general level is the level of the idea, the drama of the plot sacredness, collegiality, prophecy, the spiritual path, martyrdom, sacrificial love, the second level is the manifestation of allusions to the Sacrament of the Eucharist, the Sacrament of Confession, the third level is the presence of prayers (for the dead, supplicatory, thanksgiving), appeals, which are reminiscent in form and content of litany, bell-ringing, antiphonic singing, psalmody, and chorale. Intonation melodies: "With the saints, give rest", ascending intonation of the hexachord from V to III degrees of major, resemble "prayer leit-intonation".

The Christian ideological orientation of Tchaikovsky is doubtless, and with the formation of the composer, religious and spiritual ideas are increasingly reflected in his opera music. The operas "The Maid of Orleans" and "lolanta", which are considered in more detail in the article, are most consistent with the theme we have declared. Both operas are close in their content, in the methods of plotting and in certain stylistic features to the genre of the sacred mystery: the mystical space in which the action takes place, the demonstration of sin as a path to purification, transformation of the human soul and its approach to the Creator, the opportunity to overcome the sinful nature of a person and the possibility of its revival through liberation from shortcomings, a secret sacred act aimed at deifying a person and personal connection with the 
Creator, the symbolic path of a hero who is looking for the meaning of life. The most generalized liturgical symbols that are inherent in Tchaikovsky's opera poetics include the ideas of collegiality, eschatology, and the Eucharist; Divine Light ("Iolanta"), martyrdom ("The Maid of Orleans"), which are addressed to the main dogmatic attitudes of the Orthodox cult.

Christian cultural values and traditions were embodied through a certain liturgical symbolism, manifested at all levels: general, including the general dominant idea of the composition, which can be defined as the main line of drama, its deep focus (collegiality, the idea of the Transfiguration, hagiography, as a complex of holiness, martyrdom, sacrifice, the genre of parables (scenes from the Gospel), the style of the triune cycle of worship: evening morning or Matins, and the culminating part of the daily circle Liturgy, that is, the Divine Liturgy with the main sacrament of the Eucharist (Gratitude), with the help of which a person achieves unity with God and more private ones, through certain dramatic, stylistic, musical devices and verbal texts (features of prayer masses, funeral masses, Christmas-time symbolic complex of carols), through themes of the way of the cross and a person's choice of his fate, a reference to the events of Holy Week, through the use of the genre of prayer (conversations with God), which is seen in the musical stylistics through chorality in relation to the verbal text, which often recreates the characteristic features of a part of the mass litany, that in turn actualizes the use of the main methods of singing melodies at the mass antiphonic (performed alternately by two choirs), ipophonic or responsive (alternating performance by chorus and soloist); an appeal to the stylistics of a part-song concert, for which there is a characteristic alternation of singing by the entire composition of the choir and a separate group (soloists); and the manifestation of the characteristic features of the genre form of psalms, cants, hymns.

Liturgical symbolism is also manifested at the smallest level, in the opera score, at the level of including musical and intonational formulas, intonationally stable complexes which eventually acquired the status of a symbol, a certain sign of a complex expression of a liturgical musical intonation, verbal and semantic field, for example, a symbol of death - "Eternal memory", funeral "Holy God", "With the saints, give rest". One of them is the "leit-complex of litany" (according to E. Smagina), associated with layers of Orthodox liturgical melodies, which are characterized by variants of chants in the volume of the third, and the semantic load of which is in august, pleading, funeral or grateful appeals to God. A complex of church bells or allusions to it, musical quotes or stylizations are used, which the composer uses from his personal experience of contact with liturgical cult chants.

The multifaceted work of Tchaikovsky is an inexhaustible source for the study of philosophical, ethical, cultural depths. The unconditional presence of liturgical symbolism in musical and verbal texts at different levels of symbolization makes it possible to speak of the Christian vector in the composer's work, as one of the leading, determining the composer's belonging both to the national Orthodox 
Christian tradition and to the world Christian culture in general.

\section{Conclusion}

A comprehensive approach to the study of the creative universe of an artist-author revealed the possible components of his activity: an artistic idea, an artistic image, aesthetic emotions, interpretation, transposition, transcription, improvisation, composition, author-artistic premiere, directing and theatricalization, which compose to the universal performing creative complex, that, in turn, acts not only as a toolkit for a performerartist, but also serves as his test and characteristic to feel the pulse of his time.

In this case, the creative potential of the musician-performer is a dynamic integrative personality quality universalism, which reflects the measure of the possibilities of actualizing the person's essential forces in a focused artistic activity.

In the personality of the artist-author, "I am the performer" is never equal to "I am the author", but in general it is holistic. The result of the art of such a person is not just a certain sum of types of creativity, art, but something energetically and spiritually higher, namely, here we face with the the phenomenon of "expiration", revealed to us in the creative fruits of the outstanding pillars of performing and composer's musical culture.

This type of personality of a musician artist-author has no creative boundaries in his activity, for example, in the form of a once-for-all set musical text, or orientation to a single, albeit standard, interpretation.

Such creativity tends to infinity. The artist constantly "cuts" the images of his own compositions, like "liquid crystals", depending on time, space, public, conditions of artistic communication.

A true artist, feeling the pulse of "his" time, is constantly trying to 'find himself', to determine his place and significance in art, in the wide "ocean" of culture. This is dictated by the internal need for an academic missionary performer to be relevant to modern society, to express his "image of the world" through the play of author's music, to demonstrate his position in art the position of a citizen of the world. 


\section{Biodata of Authors}

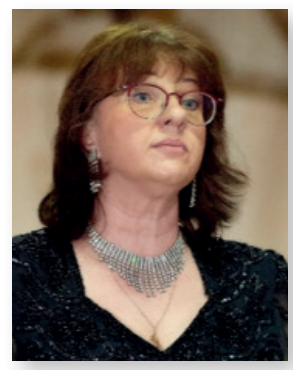

\section{Kateryna Nemchenko}

Ph.D in Art History, lecturer at the Odessa Professional College of Arts named after K.F. Dankevich and South Ukrainian National Pedagogical University named after K.D. Ushinsky. For 15 years, she taught at the Odessa National Music Academy at the department of solo singing. She worked as an artist of the Odessa State Opera and Ballet Theater, a soloist of the Odessa Regional Philharmonic. Now she is performing concert activities.

In the sphere of scientific interests, operatic creativity of Russian and Ukrainian composers and their national self-identification through the manifestation of elements of Orthodox liturgical culture, liturgical symbolism, and Christian worldview in music.

The author of the dissertation on the topic "Liturgical symbolism in opera music of the 19th - 21st centuries (based on the works of Russian and Ukrainian composers)."

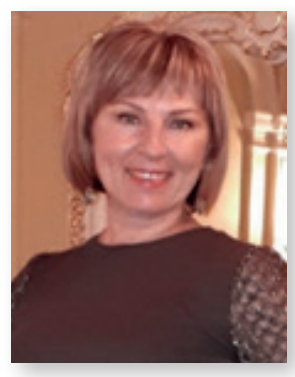

\section{Larisa Loboda}

Ph.D in Art History, vocalist, teacher of solo singing. She graduated from the Odessa State Conservatory. After graduation, she sang in the Ensemble of Soloists "Renaissance". She taught vocals at the South Ukrainian National Pedagogical University named after K.D. Ushinsky. In 1994 she began teaching at the Odessa Conservatory (now ONMA). She has conducted active concert activities. In 1994 she became a laureate of the International Competition of Opera Singers. Solomiya Krushelnytska. I have many graduates who work in theaters, philharmonics, and teach in music institutions. In 2012 she defended her dissertation and received the degree of Ph.D. in Art History. In addition, she got the title of Associate Professor.

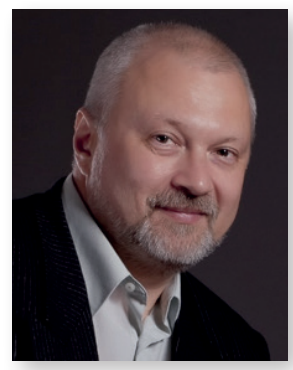

\section{Anatoliy Nosulya}

Ph.D in Art History, vocalist, teacher of solo singing. In 1983 he entered the Odessa State Conservatory named after A.V. Nezhdanov, majoring in "solo singing" in the class of Honored Artist of Ukraine, Professor E.M. Ivanov. He graduated in 1988.

From 1988 to 2000, he worked as a soloist of the Odessa Theater of Musical Comedy. During his work in the theater, he performed more than fifty roles, including leading parts in the works of famous world and domestic authors. From 1995 to 1998, he studied in the assistantship internship of the Odessa State Academy named after AV Nezhdanova. From 1998 to the present, he has worked at the Department of Solo Singing of the Odessa National Music Academy named after A.V. Nezhdanov. In 2017 he received the degree of Ph.D. in Art History, defending his dissertation on "GenreCompositional Features of the Evolution of Chamber Opera (from XIX - XXI centuries.").

Anatoliy Valentynovych is the author of numerous scientific articles, participated in many scientific conferences.

He passed international internships: 2018 - at the University “Collegium Civitas" (Warsaw, Poland) under the program "Internationalization of higher education. New and innovative teaching methods"; 2018, 2020, 2021 - in the framework of the international musicological seminar "Musicological word in the information content of (post) modernity". 


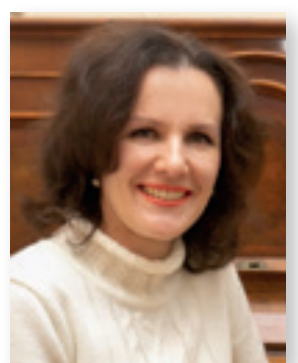

\section{Olena Kuchma}

Ph.D in Art History, musicologist, teacher of music history.

Kuchma Olena Petrovna graduated from Odessa State Music Academy named after A.V. Nezhdanov majoring in "musicology" and postgraduate research at the specified educational institution. She works as the deputy director on the scholarly work of a remarkable cycle of the Odessa State Musical Lyceum named after Prof. P.S. Stolyarsky and at the Department of History of Music and Musical Ethnography of the Odessa National Academy of Music named after A.V. Nezhdanov (part-time). Research interests: stylistic problems of music of the twentieth century, the phenomenon of dialogue in the art of music. 


\section{References}

Cherkashina, M., (1994). Tchaikovsky "The Maid of Orleans": The problem of the genre and the specific treatment of the subject. International Journal of Musicology, 3.

Hertz, H. (1883). Daughter of King Rene / transl. by F. B. Miller. Russian Bulletin. E.

Hertz, H. (1850). Daughter of King Rene. Pantheon and repertoire of the Russian stage, No. 2, Book 4.

Labik, T. (2016). Ukrainian element at the creative thinking and musical movement of P. Tchaikovsky (on the example of the opera work of the composer). Thesis for the degree of "Master". Lviv National Music Academy named after M. V. Lysenko. Lviv.

Makarova, A. L. (2017a). Tchaikovsky: author. dis. for Cand. of Art History. Ural State Conservatory named after M. P. Mussorgsky. Ekaterinburg.

Makarova, A. L. (2017b). Tchaikovsky: dis. for Cand. of Art History: 17.00.02 / Ural State Conservatory named after $M$. P. Mussorgsky. Ekaterinburg.

Pribegina, G. A. (1983). Peter Ilyich Tchaikovsky. Moscow: Music.

Schmemann, A. prot., (1996). Introduction to Liturgical Theology. Moscow: Krutitskoe Patriarchal Compound.

Sitarskaya, Y. (2006). Religious and ethical issues and stylistic processes in Russian opera in the last third of the
XIX - early XX centuries: M. Musorgsky, M. Rimsky-Korsakov: dis. for Candidate of Art Studies. 17.00.01 / National Music Academy named after P. I. Tchaikovsky. Kiev.

Tchaikovsky, P. I. (1987). Iolanta: lyric opera in one act, libretto by $M$. Tchaikovsky based on the drama by $\mathrm{H}$. Hertz "The Daughter of King Rene". Arranged for singing and piano by $\mathrm{S}$. Taneyev. Moscow: Music.

Tchaikovsky, P. I. (1979). "The Maid of Orleans" Opera in 4 acts, 6 scenes. Libretto by P. Tchaikovsky after F. Schiller - V. Zhukovsky, J. Barbier and O. Merimee. Clavier. Leningrad: Music, Leningrad branch.

Tchaikovsky, P. I. (1879). Correspondence with von N. F. von Meck., part 2. Letter 184. http://www.tchaikov.ru/1879-184. html

Tchaikovsky, P. I. - N. F. von Meck (2007). Correspondence, 1876-1890. In 4 volumes. Chelyabinsk: MPI, T. 1. 18761877.

Tchaikovsky, P. I. - N. F. von Meck (2010). Correspondence, 1876-1890. In 4 volumes. Chelyabinsk: MPI, T. 3. 18791881.

Tchaikovsky, P. The Queen of Spades. Opera in 3 acts and 7 scenes. Libretto by M. Tchaikovsky. Orchestral score (in 16). Moscow: P. Yurgenson's music printing.

Tchaikovsky, P. (1940). Cherevichki: comic-fantastic opera in 4 acts (8 scenes). Libretto by Y. Polonsky. Clavier. Moscow - Leningrad: State Musical 
Publishing House.

Trubetskoy, E. I. (2011). The sense of life. Moscow: Institute of Russian Civilization.

Varavkina-Tarasova, N. (2018). Aria of Joanna d'Ark No. 7 from the opera "The Maid of Orleans" by P. Tchaikovsky: spiritual symbolism of the canon of repentance during the "probation under the sign". Problems of interaction, education, pedagogy and theory and practice. Cognitive music knowledge: collection of scientific articles of KhNUM named after I. P. Kotlyarevsky. Kharkiv: KhNUM named after I. P. Kotlyarevsky.

Zakharova O. (1990). Tchaikovsky reads the Bible. Cultural-historical journal Our legacy. № 2. Moscow. 
